\title{
FILSAFAT MANUSIA MENURUT MUHAMMADIYAH
}

\author{
Tabah Sulistyono \\ Madrasah Ibtidaiyah Muhammadiyah Karanganyar \\ E-Mail: sulistyo_tabah88@yahoo.co.id
}

\begin{abstract}
This thesis is aim to observe human philosophical system in Muhammadiyah thought. The object being discussed in this research are the teories which discussed the essense of human being and the possition of philosopical human-being in Muhammadiyah. The main sourses are KH. Ahmad Dahlan's thought and Muhammadiyah ideology and steps. The other supportiy sourches are the consideration of activist in otonom organization who uses the name of Muhammadiyah or the researcher outsider of Muhammadiyah. This research uses qualitativerasionalistic paradigma. This kind of research based on its range is religius research. Based on its type is explorative research. It uses philosophical research. The researcher observes the data by the steps of follows: first, observius the datas philosophycally,e.g. ontology, epistemology and axiology. Second, observity datas philosophically though verstehen (understanding) method such as, symbolic step, interpreting and digging step, constructive step or symbolic of life. Third, the result of verstehen is presented by expressing and explaining method. The human philosophycal ontology discussion in Muhammadiyah thought textually is only to understand one point of view of leaning personal and camera-view. Human philosophical epistemology in Muhammadiyah thingking. The are two methods to understand human-being, by purifity the heart by remembering of Allah, sholat and the thinking about heveafter purily. Third,human philosophical axsiology in Muhammadiyah which involes unity, believes, ovenminded, propetis-humanis, responsibility, and religiousity. Obviously, there are two models of human according to Muhammadiyah e.g. enlightened human (rausyan-fikr-Muhammadiyah) and monodualis or monodualist-Muhammadiyah. The concept of human philosophies in Muhammadiyah is existentialist-idealist. The Muhammadiyah is the man who are thinking for act or the man who just act in worship.
\end{abstract}

Keywords: axiology, beramal, epistemology, Muhammadiyah, ontology.

Abstrak: Tujuan tesis ini adalah mencari konsep filsafat manusia dalam pemikiran Muhammadiyah. Persoalan yang dibahas dalam penelitian iniadalah teori-teoriyang membahas esensi manusia dan kedudukan filsafat manusia dalam pemikiran Muhammadiyah. Sumber utamanya adalah pemikiran KH. Ahmad Dahlan, ideologi dan langkah Muhammadiyah. Sedangkan sumber pendukungnya adalah pemikiran aktifis ortom yang mengunakan nama Muhammadiyah atau para peneliti outsider Muhammadiyah. Penelitian ini menggunakan paradigma kualitatif-rasionalitik. Jenis penelitian ini berdasarkan ruang lingkupnya termasuk penelitian keagamaan, berdasarkan tipe penelitian, termasuk penelitian eksploratif, dan menggunakan pendekatan filsafat. Peneliti mengalisa data menggunakan langkah-langkah sebagai berikut: pertama, menganalisa data dengan filsafat ilmu, yaitu ontologi, epistemologi dan aksiologi. Kedua, menganalisa secara filosofis data-data tersebut dengan metode verstehen (pemahaman), yaitu tahap simbolik, tahap pemaknaan atau penggalian, tahap kontruktif atau kehidupan simbol dan tahap interpretasi. Ketiga, hasil dari verstehen disajikan dengan metode pengungkapan atau metode penerangan. Kajian ontologi filsafat manusia dalam pemikiran Muhammadiyah secara tekstual hanya memahami dari salah satu sudut atau meminjam 
Leaming personal and camera view. Kedua, epistemologi filsafat manusia dalam pemikiran diri Muhammadiyah. Ada dua cara atau jalan untuk memahami diri manusia, yaitu dengan penyucian hati dengan cara dzikrullah, sholat dan memikirkan tragedi kedasyatan akhirat serta dengan tafakkur (berfikir sejernih-jernihnya). Ketiga, aksiologi filsafat manusia dalam pemikiran diri Muhammadiyah. Produknya adalah sifat-sifat humanitas yang meliputi persatuan, amanah atau kepercayaan, keterbukaan, propetis-humanis, tanggungjawab, dan nilai religiuitas. Setidaknya ada dua model manusia secara nyata menurut Muhammadiyah, yaitu model manusia tercerahkan atau rausyan-fikr-Muhammmadiyah dan model manusia monodualis atau monodualis-Muhammadiyah. Paham atau aliran filsafat manusia dalam Muhammadiyah adalah eksistensialis-idealis. Realnya adalah manusia yang hanya berfikir untuk beramal atau manusia yang hanya beramal saja yang disebut manusia Muhammadiyah.

Kata kunci: aksiologi, beramal, epistemologi, Muhammadiyah, ontologi.

\section{PENDAHULUAN}

Persoalan tentang hakikat manusia dalam kajian filsafat mempunyai tempat tersendiri dan bahkan sebagian kajian filsafat mencari tentang hakikat manusia. Menurut Zainal Abidin, ada dua aliran tertua dan terbesar dalam menyikapi dan merumuskan hakikat atau esensi manusia, yaitu materialisme dan idealisme. Materialisme sebagai sebuah paham filsafat yang meyakini bahwa esensi dari kenyataan yang ada adalah material itu sendiri, hal ini juga merembet ke dalam esensi manusia, yaitu badan itu sendiri. Sebagai cirinya apabila kenyataan yang ada tersebut dapat diukur, memiliki keluasaan, bersifat objektif dan tentunya menempati ruang. Rumusan yang bertolak belakang disampaikan oleh idealisme, yaitu aliran filsafat yang meyakini ada kekuatan spiritual di balik kenampakan yang ada atau jelasnya hakikat dari sesuatu yang ada adalah bersifat spiritual. Sesuatu yang ada tersebut juga menyangkut diri manusia. ${ }^{1}$ Kedua aliran besar diatas termasuk dalam kategori aliran esensi tunggal atau sering disebut sebagai monisme. Ada yang berpaham bahwa dalam diri sesuatu yang ada itu mempunyai dua subtansi atau esensi fisik dan esensi spiritual, maka sering mendapatkan label dualisme.

1 Zainal Abidin, Filsafat Manusia: Memahami Manusia Melalui Filsafat, Cet. Keenam, (Bandung: PT Remaja Rosdakarya, 2011), hlm.25-27.
Manusia sebagai persona mempunyai komponen penyusun manusia itu, yaitu roh, jiwa (nafs) dan badan atau jasmani. Ketiga unsur penyusun manusia ini menjadi bahan kajian yang panjang dalam rentetan sejarah manusia. Ketiganya tentu mempunyai fungsi masing-masing yang berlawanan tetapi saling menguatkan. Eksistensi jiwa dalam tubuh akan memberikan warna secara total bagi kemungkinan 'ada'nya didunia dan akan menentukan kemungkinan perbuatan yang dilakukannya. Fungsi yang terakhir inilah manusia dapat menentukan perbuatannya sendiri dengan kehendak bebas. Kebebasan ini dapat dikaitkan dalam tiga hal, yaitu kebebasan dalam penyempurnaan diri, kemampuan untuk memilih dan memutuskan, dan kemampuan untuk dapat mengungkapkan berbagai dimensi manusia. ${ }^{2}$ Point terakhir inilah yang dapat melahirkan berbagai peradaban didunia ini yang menakjubkan. Sehingga didalam sebuah peradaban yang dibangun itu, tentu ada pemahaman tentang hakikat manusia, baik terdapat dalam sistem ideologinya atau ilmu yang dipelajarinya. Hal ini akan menarik ketika disentuhkan dengan gerakan Muhammadiyah yang telah berusia satu abad. Setidaknya, ada tiga alasan penelitian yang berkaitan dengan Muhammadiyah ini dilakukan, yaitu pertama ormas keagamaan yang menekankan tajdid (pembaruan) dalam

2 Kasdin Sihotang, Filsafat Manusia: Upaya Membangkitkan Humanisme, cet. 5, (Yogyakarta: Kanisius, 2009), hlm.75. 
berbagai bidang. Kedua, karena gerakan ini lebih mengutamakan dan menekankan peranan aspek akal dan pikiran dalam berdiin dibanding mengandalkan kepekaan hati dan intuisi. ${ }^{3}$ Ketiga, adanya peradaban yang telah di bangun oleh Muhammadiyah.

Peradaban dalam Muhammadiyah ini muncul dari gerakan Muhammadiyah sebagai pelopor gerakan pembaruankeagamaan modern di Indonesia, sebuah gerakan pemberdayaan masyarakat dan gerakan keilmuan atau pemikiran yang dapat diperhitungkan. Gerakan keilmuan (rasionalisme) ini muncul dari ciri khusus yang melekat pada diri Muhammadiyah ini yang di sampaikan oleh Abdul Munir Mulkhan, yaitu adanya ciri pertumbuhan dan kemajuan. Kedua adalah sistematisasi sebagai prinsip. Prinsip ini keluar dari rumus utama dari gerakan modernisme yang lainnya, tidak lain gerakan tersebut adalah rasionalisme. ${ }^{4}$

Pandangan tentang manusia secara filosofis berkaitan erat dan bahkan merupakan bagian dari sistem ideologi gerakannya. Sistem ideologi gerakan adalah landasan 'moral' organisasi, yang akhirnya akan memperlihatkan corak peradabannya. Pandangan tentang hakikat manusia dengan demikian merupakan masalah sentral yang akan mewarnai corak berbagai segi peradaban yang dibangun Muhammadiyah diatasnya. Oleh karena itu, konsep manusia secara filosofis penting bukan demi pengetahuan akan manusia itu sendiri, tetapi yang lebih penting adalah karena ia merupakan syarat bagi pembenaran kritis dan landasan yang aman bagi terbentuknya masyarakat Islam yang sebenar-benarnya. Inilah satu kegelisahan akademik dari penelitian ini.

Ada beberapa penelitian yang mendahului penelitian ini. Penelitian yang dilakukan oleh Saudara Syamsul Hidayat dengan judul Pemikiran Muhammadiyah

3 Masyitoh Chusnan, Tasawuf Muhammadiyah: Menyelami Spirituall Leadership AR Fakhruddin, Cetakan II (Jakarta: Kubah Ilmu, 2012), hlm. 43.

4 Abdul Munir Mulkhan, Mengggugat Muhammadiyah, (Yogyakarta: Fajar Pustaka, 2000), hlm. 14. tentang Pluralitas Budaya. Penelitian ini setidaknya akan menjawab pertanyaanpertanyaan yang belum dicari jawabannya dari penelitian diatas, seperti bagaimanakah pemikiran esensi manusia dalam gerakan Muhammadiyah sebagai landasan secara filosofis dalam mewujudkan peradaban utama di Indonesia. Agaknya, secara kronologis penelitian ini akan memberikan ruang yang filosofis terhadap hakikat dari sebuah budaya, karena budaya merupakan interpretasi dari bagaimana cara memandang manusia. Inilah pertanyaan yang diharapkan dapat terjawab dari penelitian ini. Penelitian yang dilakukan oleh Sudara Arbiyah Lubis dengan judul penelitian Pemikiran Muhammadiyah dan Muhammad Abduh (Suatu Studi Perbandingan). Diperlukan penelitian lanjutan tentang hal ini, setidaknya ada pandangan pemikiran konsep manusia yang lebih komprehensif dan filosofis dari pemikiran Muhammadiyah, inilah persoalan yang akan terpecahkan dalam penelitian ini yang akan melanjutkan penelitian dari Arbiyah Lubis diatas, karena penelitian tersebut belum terfokus terhadap entitas-entitas dari dapur Muhammadiyah.

Berdasarkan latar belakang dan telaah pustaka yang diuraian di atas, maka peneliti merumuskan masalah yaitu: bagaimana konsep filsafat manusia menurut Muhammadiyah? Rumusan masalah diatas akan membahas tentang teori-teori hakikkat manusia yang dikemas dalam kajian filsafat ilmu, terdiri dari ontologi filsafat manusia, epistemologi filsafat manusia dan aksiologi filsafat manusia. Tujuan dari penelitian ini adalah untuk mengetahui konsep filsafat manusia menurut Muhammadiyah.

\section{METODE PENELITIAN}

Penelitian ini menggunakan kerangka pemikiran objek formalnya filsafat ilmu dan objek materinya Muhammadiyah. Penelitian ini menggunakan paradigma penelitian kualitatif-rasionalitik. ${ }^{5}$ Jenis penelitian ini

5 Neong Muhajir, Metode Penelitian Kualitatif: Telaah Positivistik, Rasionalistik Dan Phenomenologik, 
berdasarkan ruang lingkupnya termasuk penelitian keagamaan. ${ }^{6}$ Penelitian ini dapat dikelompokkan kedalam penelitian literer. ${ }^{7}$ Sedangkan berdasarkan tipe penelitian, penelitian ini termasuk penelitian eksploratif. Pendekatan yang digunakan adalah pendekatan filsafat.

Pemikiran Muhammadiyah dalam penelitianiniadalah hasil permusyawaratan, pemikiran tokoh Muhammadiyah dan pemikiran KH.Ahmad Dahlan dan tafsir AtTanwir dalam suara Muhammadiyah. Dari awal penelitian ini didesain mengunakan paradigma kualitatif rasionalistik, maka dalam pengumpulan datanya mengunakan teknik dokumentasi atau naskah. Penelitian ini menggunakan sumber primer dan sumber sekunder.

Peneliti mengalisa data menggunakan langkah-langkah sebagai berikut: pertama, menganalisa data dengan filsafat ilmu, yaitu ontologi, epistemologi dan aksiologi. Kedua, menganalisa secara filosofis datadata tersebut dengan metode verstehen (pemahaman), yaitu tahap simbolik, tahap pemaknaan atau penggalian, tahap kontruktif atau kehidupan simbol dan tahap interpretasi. Ketiga, hasil dari verstehen disajikan dengan metode pengungkapan atau metode penerangan. ${ }^{8}$

\section{HASIL DAN PEMBAHASAN}

\section{Filsafat Manusia}

\section{a. Ontologi Filsafat Manusia}

Ontologi filsafat manusia dalam pengertian ini meliputi pengertian manusia dengan menggunakan teori yang di sampaikan oleh Laming,

\section{(Jakarta: Rake Sarasin, 1989), hlm. 76-110.}

6 Taufik Abdullah, "Kata Pengantar" dalam Taufik Abdullah dan M. Rusli Karim (ed.), Metodologi Penelitian Agama Sebuah Pengantar, (Yogjakarta: Tiara Wacana, 1989), hlm. xiii.

7 Neong Muhajir, Metode Penelitian Post-Positivisme dan Post-Modernisme Post-Positivisme dan PostModernisme. Ed.II. Cetakan 1. Yogyakarta: Rake Sarasin, 2001), hlm.41.

8 Kaelan, Metode Penelitian Kualitatif Interdispliner Bidang Sosial, Budaya, Filsafat, Seni, Agama dan Humaniora, (Yogyakarta: Paradigma, 2012), hlm. 180-185. pertama, apa yang disebut sebagai perilaku semi mekanis dari manusia. Kedua, dengan mengambil celah dari sudut pandang pertama, Laming menyebut teori ini dengan sudut pandang personal atau sudut pandang kamera (personal and camera view). Ketiga, dengan sudut pandang teori pengaruh sosial. ${ }^{9}$ Menurut Adelbert Snijders ada beberapa hal menyangkut tentang berbagai sisi manusia, yaitu pertama, manusia sebagai makhluk yang selalu bertanya. Kedua, manusia sebagai makhluk yang eksentris. Ketiga, manusia sebagai makhluk paradoksal. Keempat, manusia adalah makhluk yang dinamis. Kelima, manusia sebagai makhluk multidimensional. ${ }^{10}$ Esensi berkaitan dengan hakikat manusia, maka berkaitan dengan unsur penyusun manusia itu, ruh dan jasad. Esensi dari manusia itu terletak dalam ruh sebagai peparing Tuhan atau jasad yang terbuat dari unsur tanah, malah kedua-duanya sebagai esensi atau hakikat manusia yang sering dilabeli dualisme atau monodualis. ${ }^{11}$

\section{b. Epistemologi Filsafat Manusia}

Epistemologi menyangkut penciptaan manusia yang menggunakan teori penciptaan kreasionisme. Hal ini berarti bahwa dunia fisik dan segala yang ada di dalamnya ada secara obyektif dan secara nyata; dunia fisik bukan rupa dan ilusi. Gagasan penciptaan dunia dan (peng)ada-(peng)ada hanya mempunyai arti jika dunia ada secara nyata, dengan suatu eksistensi yang khas baginya. Penciptaan berarti alam semesta secara fisik bukan "ada" mutlak, dan tidak mencukupi untuk dirinya sendiri. Dengan demikian, alam semesta secara fisik didedivisasi dan di

9 Reza AA Wattimena, G Dewi Nugrohadi dan A. Untung Subagya, Menjadi Manusia Otentik, (Yogyakarta: Graha Ilmu, 2013), hlm. 9-10.

10 Lihat Murtadho Mutahari, Perspektif Al-Quran tentang Manusia dan Agama, (Bandung: Mizan, 1992), hlm. 125.

11 Tim Penulis Rosda, Kamus Filsafat, (Bandung: PT. Remaja Rosda Karya, 1995), hlm. 99-100. 
deklarasi. Alam semesta itu ada, tetapi ia bukan "ada" yang mutlak. Ia bersifat kontingen dan tergantung pada Dia, satu-satunya yang dapat memberikan keadaan. Ia tergantung pada Ada yang mutlak, yaitu Allah. ${ }^{12}$

\section{c. Aksiologi Filsafat Manusia}

Nilai-nilai humanitas yang hendak dikaji dalam penelitian ini adalah nilai-nilai persatuan, amanah atau kepercayaan, keterbukaan, propetikhumanis, tanggung jawab, dan nilai religiuitas manusia. ${ }^{13} \quad$ Kebebasan dalam memahami diri ini menyangkut potensialitas dan aktualitas manusia sebagai jenis maupun sebagai pribadi. $^{14}$ Ada potensialitas yang perlu di perhatikan yaitu potensialitas tentang cara memahami diri sendiri (penyempurnaan) diri. $^{15} \quad$ Nilai-nilai diatas akan bergumpul dalam kualitas manusia Muhammadiyah. Model manusia rausyan-fikr Ali Syari'ati ${ }^{16}$, model monodualis Notonegara dan model insan kamil Hamzah Fansuri.

\section{Pemikiran Muhammadiyah tentang Filsafat Manusia}

\section{a. Ontologi Dan Hubungan Manusia}

Manusia mempunyai peran dan posisi khusus diantara komponen alam dan makhluk ciptaan Tuhan yang lain yakni sebagai khalifah, wakil Tuhan dan pemimpin dibumi. ${ }^{17}$ Menurut Leaming,

12 Louis Leahy SJ, Filsafat Ketuhanan Kontemporer, (Yogyakarta: Kanisius dan BPK Gunung Mulia), hlm. 203-207.

13 Ibid, hlm. 38-42, 112-118

14 Adelbert Snijders, Antropologi Filsafat Manusia: Paradoks dan Seruan,(Yogyakarta: Kanisius, 2004), hlm. 165-171.

15 Anton Bakker, Antropologi Metafisik, (Yogyakarta: Kanisius, 2000), hlm. 78-79.

16 Ali Syari'ati, Membangun Masa Depan Islam: Pesan untuk Intelektual Muslim, Cet. V, terj. Rahmani Astuti, (Bandung: Mizan, 1995), hlm. 24.

17 Majelis Lingkungan Hidup PP Muhammadiyah, Teologi Lingkungan: Etika Pengelolaan Lingkungan dalam Perpektif Islam, Cetakan II, (Jakarta: Deputi Komunikasi Lingkungan dan Pemberdayaan Masyarakat, Kementerian Lingkungan Hidup dan Majelis Lingkungan Hidup Pimpinan Pusat Muhammadiyah, 2011), hlm.6-9. pengertian manusia diatas termasuk dalam kategori sudut pandang yang kedua, yaitu sudut pandang satu arah (personal and camera view). Satu arah tersebut adalah arah manusia dalam berhubungan dengan alam raya yang mempunyai tiga hubungan yang saling menguntungkan. Menurut Adelbet Snijders, pengertian manusia diatas bertolak dari kata 'hubungan', hubungan manusia dengan alam raya, hubungan manusia dengan sesamanya dan hubungan manusia dengan Tuhan.

Penciptaan Adam sebagai bapak manusia (abu al-basyar) dalam beberapa ayat dijelaskan secara umum materinya berasal dari at-turab (tanah). Proses penciptaannya melalui firman kun, (jadilah), dan kemudian jadilah manusia pertama itu fayakun. ${ }^{18}$ Manusia terdiri dari tubuh dan ruh. ${ }^{19} \mathrm{Hal}$ ini dikuatkan oleh pendapat Djarnawi Hadikusuma, manusia terdiri dari dua unsur pokok yaitu jasmani dan rohani. ${ }^{20}$

\section{b. Epistemologi Filsafat Manusia Menurut Muhammadiyah}

1) Konsep Penciptaan Manusia Muhammadiyah

Muhammadiyah mempunyai pemikiran bahwa manusia tercipta bukan dari evolusi dari seekor kera besar tetapi berasal dari keturunan Nabi Adam as. Jelasnya, pemikiran Muhammadiyah berkaitan dengan penciptaan manusia menganut paham kreasionis, tepatnya kreasionis-teistik. ${ }^{21}$

18 KHR. Hadjid, Pelajaran KHA. Dahlan:7 Falsafah Ajaran dan 17 Kelompok Ayat Al-Qur'an, Cetakan kelima, (Yogyakarta:2013), hlm.7-11.

19 Majelis Tarjih dan Tajdid Pimpinan Pusat Muhammadiyah "Manusia: Konsep Penciptaan Untuk Memperoleh Kemuliaan Hidup (1)", Tafsir At-Tanwir, Suara Muhammadiyah, No.9/Th ke-98, 1-15 Mei 2013, hlm.19.

20 Pimpinan Pusat Muhammadiyah, Pedoman Islami Warga Muhammadiyah, Edisi Revisi, (Yogyakarta: Suara Muhammadiyah, 2010), hlm. 5.

21 Majelis Tarjih dan Tajdid Pimpinan Pusat Muhammadiyah "Manusia: Konsep Penciptaan Untuk 
2) Jalan Memahami Diri Manusia

a) Pensucian Hati atau Riyadhah Hati

Konsep pensucian hati ini berlaku di diri Muhammadiyah. Kosep naikinimelalui Kyai Dahlan diintroduksi menjadi cara membersihkan hawa nafsu atau dapat mengetahui dan mengenal Tuhan dengan pengenalan yang sebenarbenarnya. Pendeknya, Kyai Dahlan telah merumuskan jalan atau epistemologi untuk mengetahui hakikat diri manusia dalam diri Muhammadiyah. Epistemologi yang dimaksud adalah dzikrullah, memperbanyak sholat, memikirkan tragedi akhirat.

b) Tafakkur

Cara berikutnya adalah berfikir mengunakan akal yang sehat. Akal yang sehat adalah akal yang tidak tercemari bahaya, dapat memilih dengan pertimbangan yang cermat dan memegang teguh pilihan tersebut. Manusia yang 'mengerti' (pintar) akan berusaha menjaga akal agar tetap memperoleh kesempurnaan dan dapat memahami dirinya, cara menjaga akal tersebut dengan, pertama, jika memilih suatu perkara dengan rasa cinta dan kasih sayang "kebijaksanaan". Kedua, berusaha dengan sungguh-sungguh. Ketiga, memilih sesuatu dengan jelas. Keempat, niat

Memperoleh Kemuliaan Hidup (1)", Tafsir At-Tanwir, Suara Muhammadiyah, No.8/Th ke-98, 16-30 April 2013, hlm.19. baik dalam menetapkan dan peneguhan pilihan yang dicarinya. Kelima, memelihara amanah yang telah diperolehnya. Keenam, menempatkan sesuatu pada tempatnya. ${ }^{22}$

\section{3) Aksiologi Filsafat Manusia} menurut Muhammadiyah

a) Nilai-nilai Humanitas Menurut Muhammadiyah

Nilai-nilai yang dikembangkan dalam pemikiran Muhammadiyah adalah persatuan, amanah atau kepercayaan, keterbukaan, propetishumanis, tanggungjawab dan nilai religiuitas.

b) Kualitas Manusia Muhammadiyah

$\mathrm{M} \mathrm{u} \mathrm{h}$ a m m a d i y h memberikan terminologi manusia-manusia yang berkualitas itu dengan kata manusia muslimin. $\mathrm{Muh}$ a $\mathrm{m} \mathrm{m} \mathrm{m} \mathrm{a} \mathrm{d} \mathrm{i} \mathrm{y} \mathrm{a} \mathrm{h}$ memberikan beberapa karakteristik apa yang disebut sebagai manusia muslimin, yaitu pertama berkepribadian mu'min. $^{23}$ Kedua, kepribadian muhsin. Ketiga, kepribadian muttaqin. Allah menjelaskan sebagian tanda-tanda orang muttaqin, yaitu beriman kepada yang gaib; mendirikan shalat; dan memberikan infaksedekah.

22 Abdul Munir Mulkhan, Pemikiran KH. Ahmad Dahlan, dan Muhammadivah:dalam Perspektif Perubahan Sosial, (Jakarta: Bumi Aksara, 1990), hlm.228-229.

23 Tim Majelis Tarjih dan Tajdid Pimpinan Pusat Muhammadiyah, Fatwa-Fatwa Tarjih Tanya Jawab Agama 2, Cetakan Ketujuh, (Yogyakarta:Suara Muhammadiyah, 2012), hlm. 22. 
3. Model Manusia Muhammadiyah

a. Rausyan-Fikr Muhammadiyah

Pemikiran pendiri Muhammadiyah

KH Ahmad Dahlan ketika merubah masyarakat Kauman. Masyarakat Kauman sebelum Muhammadiyah berdiri adalah masyarakat yang tidak tercerahkan. Hal ini dapat dilihat dari kegiatan dan kehidupan sehari-hari masyarakat tersebut. Muhammadiyah mendorong masyarakat Kauman untuk menciptakan gerakangerakan besar yang revolusioner, yang konstruktif, yang mengubah masyarakat beku, yang statis dan yang mandek menjadi masyarakat yang memiliki arah, gaya hidup, pandangan, budaya dan nasib yang bagus.

b. Monodualis Muhammadiyah

1) Susunan Kodrat Manusia Menurut Muhammadiyah

Hakekat manusia sebagai susunan kodrat manusia Muhammadiyah terdiri atas jiwa (rukhani) yang tidak maujud berupa benda atau materi dan badan atau wadah yang terdiri dari unsur-unsur tanah. ${ }^{24}$

2) Sifat Kodrat Manusia Menurut Muhammadiyah

Manusia mempunyai sifat kodrat sebagai pribadi (perorangan) dan sebagai warga masyarakat (jama'ah) yang hidup bersama atau makhluk sosial. ${ }^{25}$

3) Kedudukan Kodrat Manusia Menurut Muhammadiyah Manusia mempunyai kedudukan kodrat sebagai

24 Majelis Tarjih dan Tajdid Pimpinan Pusat Muhammadiyah "Manusia: Konsep Penciptaan Untuk Memperoleh Kemuliaan Hidup (1)", Tafsir At-Tanwir, Suara Muhammadiyah, No.9/Th ke-98, 1-15 Mei 2013, hlm.18-19.

25 Pimpinan Pusat Muhammadiyah, Pedoman Hidup Islami Warga Muhammadiyah, Edisi Revisi. Yogyakarta: Suara Muhammadiyah.hlm.8-9, 11. pribadi yang berdiri sendiri dan sebagai makhluk Tuhan. Perbuatan manusia dilihat dari segi kuasanya dinamakan hasil usaha sendiri, manusia merupakan penerima gerak. Tetapi dilihat dari segi kekuasaan Allah Swt, perbuatan manusia itu adalah ciptaan Allah, ini menunjukkan dengan kekuasaan Allah Swt perbuatan manusia diciptakan. Jika Allah Swt tidak memberikan kekuasaanNya kepada manusia untuk bergerak atau berbuat, maka manusia tidak akan dapat bergerak, tetapi Allah Swt memberikan kekuasaanNya kepada manusia untuk bergerak sesuka hati.

\section{Eksistensialis-Idealis: Paham Manusia Muhammadiyah}

Konsep manusia yang ada dalam kajian ini dalam arti kedudukan manusia dalam Muhammadiyah adalah diantara eksistensialis dan idealis atau lebih singkatnya eksistensialis-idealis. Manusia Muhammadiyah berkeinginan untuk berada, ada dengan sesungguhnya, bukan ada yang semu, abu-abu atau hanya bayangbayangan saja. Manusia yang hanya berfikir untuk beramal atau manusia yang hanya beramal saja yang disebut manusia Muhammadiyah. Nilai spiritual yang ada di dibalik ber-ada untuk beramal adalah balasan diakhirat atau lebih dekat dengan Tuhan. Manifestasi dari balasan ini adalah jannatun-naim.

\section{KESIMPULAN}

Kajian ontologi filsafat manusia berarti mengkaji asal-muasal manusia. Manusia dalam pemikiran Muhammadiyah secara tekstual hanya memahami dari salah satu sudut atau meminjam Leaming personal and camera view. Kedua, epistemologi filsafat manusia menurut Muhammadiyah. Ada 
dua cara untuk memahami diri manusia, yaitu pertama, penyucian hati dengan cara dzikrullah, sholat dan memikirkan tragedi kedasyatan akhirat. Kedua, tafakkur (berfikir sejernih-jernihnya). Ketiga, aksiologi filsafat manusia menurut Muhammadiyah. Produknya adalah sifat-sifat humanitas yang meliputi persatuan, amanah atau kepercayaan, keterbukaan, propetishumanis, tanggungjawab dan nilai religius. Setidaknya ada dua model manusia secara nyata menurut Muhammadiyah, yaitu model manusia tercerahkan atau rausyan-fikr-Muhammmadiyah dan model manusia monodualis atau monodualisMuhammadiyah. Paham atau aliran filsafat manusia dalam Muhammadiyah adalah eksistensialis-idealis. Singkatnya, adalah manusia yang hanya berfikir untuk beramal atau manusia yang hanya beramal saja yang disebut manusia Muhammadiyah.

\section{DAFTAR PUSTAKA}

Abidin, Zainal. 2011. Filsafat Manusia: Memahami Manusia Melalui Filsafat. Cetakan Keenam. Bandung: PT Remaja Rosdakarya.

Bakker, Anton. 2000. Antropologi Metafisik. Cetakan ke-7. Yogyakarta: Kanisius Bekerjasama dengan Yayasan Adikarya Ikapi Dan The Ford Foundation.

Chusnan, Masyitoh. 2012. Tasawuf Muhammadiyah: Menyelami Spirituall Leadership AR Fakhruddin. Cetakan II. Jakarta: Kubah Ilmu.

Kaelan. 2012. Metode Penelitian Kualitatif Interdispliner Bidang Sosial, Budaya, Filsafat, Seni, Agama dan Humaniora. Yogyakarta: Paradigma.

Leahy, Louis SJ. 1993. Filsafat Ketuhanan Kontemporer. Yogyakarta: Kanisius dan BPK Gunung Mulia.

Majelis Lingkungan Hidup PP Muhammadiyah. 2011. Teologi Lingkungan: Etika Pengelolaan Lingkungan dalam Perpektif Islam. Cetakan II. Jakarta: Deputi Komunikasi Lingkungan dan Pemberdayaan Masyarakat, Kementerian Lingkungan Hidup dan Majelis Lingkungan Hidup Pimpinan Pusat Muhammadiyah.

Majelis Tarjih dan Tajdid Pimpinan Pusat Muhammadiyah "Manusia: Konsep Penciptaan untuk Memperoleh Kemuliaan Hidup (1)", Tafsir At-Tanwir, Suara Muhammadiyah, No.8/Th ke-98, 16-30 April 2013.

Majelis Tarjih dan Tajdid Pimpinan Pusat Muhammadiyah “Surat Al-Baqarah 1-5 (2)", Tafsir At-Tanwir, Suara Muhammadiyah, No.13/Th ke-97, 1-15 Juli 2012.

Muhadjir, Neong. 2007. Metode Keilmuan Paradigma Kualitatif, Kuantitatif dan Mixed. Edisi V. Jakarta: Rake Sarasin.

1989. Metode Penelitian Kualitatif: Telaah Positivistik, Rasionalistik dan Phenomenologik. Jakarta: Rake Sarasin.

Mulkhan, Abdul Munir. 1990. Pemikiran KH. Ahmad Dahlan, dan Muhammadiyah:dalam Perspektif Perubahan Sosial. Jakarta: Bumi Aksara.

2000. Mengggugat Muhammadiyah. Yogyakarta: Fajar Pustaka.

Mutahari, Murtadho. 2012. Perspektif Al-Quran tentang Manusia dan Agama. Bandung: Mizan.

Pimpinan Pusat Muhammadiyah. 2010. Pedoman Islami Warga Muhammadiyah. Edisi Revisi. Yogyakarta: Suara Muhammadiyah.

Sanadji, Kasmiran Wuryo. 1985. Filsafat Manusia. Jakarta: Erlangga.

Sihotang, Kasdin. 2009. Filsafat Manusia: Upaya Membangkitkan Humanisme. Cetakan 5. 
PROFETIKA, Jurnal Studi Islam, Vol. 17, No. 2, Desember 2016: 50-58

Yogyakarta: Kanisius.

Snijders, Adelbert. 2004. Antropologi Filsafat Manusia: Paradoks dan Seruan. Yogyakarta: Kanisius.

Syari'ati, Ali. 1995. Membangun Masa Depan Islam: Pesan Untuk Intelektual Muslim. Cet. V. Diterjemahkan oleh Rahmani Astuti. Bandung: Mizan.

Taufik Abdullah, "Kata Pengantar" dalam Taufik Abdullah dan M. Rusli Karim (ed.). 1989. Metodologi Penelitian Agama Sebuah Pengantar. Yogjakarta: Tiara Wacana.

Tim Penulis Rosda. 1995. Kamus Filsafat. Bandung: PT. Remaja Rosda Karya.

Wattimena, Reza AA, G Dewi Nugrohadi dan A. Untung Subagya. 2013. Menjadi Manusia Otentik. Yogyakarta: Graha Ilmu. 